\title{
Consuming Leisure Time: How The Tourism Trend Has Changed The Village
}

\author{
Ratna Istriyani \\ UIN Sunan Kalijaga Yogyakarta, \\ ratna.istriyani@uin-suka.ac.id
}

\begin{abstract}
This article explores the concept of leisure time and its connections to trends in tourism. Examining the specific implications of tourist agendas on previously 'rural' villages, this study demonstrates how the tourist agenda has shaped leisure time and contributed to the transformation of places into more commercial, tourist hubs, aiming to maximize consumer attraction. Crucially, new economic features associated with the tourism trade have altered social relations and dynamics in rural areas. These changes can also be seen in Yogyakarta, especially villages in the Sleman area. This study uses qualitative methods to explore the economic changes experienced within the village associated with its formation as a tourist destination, drawing on observational and secondary data sets. Changes in economic patterns, generally, cannot be separated from the tourism trend. In this article, tourism trend refers to consumer market which emphasizing the modification of classical nuances which refers to the proliferation of restaurants and cafes in rural areas at Sleman. This study argues that the tourism trend in rural areas has not only changed their economic complexion but has also highlighted the character of the village as a space for urban community consumption. The economic shift from the expansion of the tourism sector is assumed to be able to contribute to development of rural areas. However, it is not necessarily possible to realize that sustainable regional development demand creativity to compete with the emergence of new entertainment venues.
\end{abstract}

Keywords: Tourism Transformation, Village, Leisure, Space Consumption.

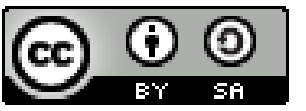

Copyright $\odot 2021$ by Author(s)

This work is licensed under a Creative Commons Attribution-ShareAlike 4.0 International License. All writings published in this journal are personal views of the authors and do not represent the views of this journal and the author's affiliated institutions.

\section{HOW TO CITE:}

Istriyani, Ratna. "Consuming Leisure Time: How The Tourism Trend Has Changed The Village "(2021) l:1 Contemporary Sociological Issues 17-34.

Submitted :October 14, 2020

Revised :November 20, 2020
Accepted

Publish
:January 2, 2021

: February 5, 2021 



\section{INTRODUCTION}

Tourism become a trend and life necessity for today's society because the fatigue from work that is increasingly complex whack them, especially for urban people. Therefore, the times between work or vacations are often used to looking for entertainment. High social demand for recreational activities has led to the transformation spaces into tourist attractions and recreational facilities. The entrepreneurial character of the tourist trade has established a promising economic foundation. The visibility of tourist locations on social media platforms, such as Facebook and Instagram, not only demonstrates the vast number of destinations available, but can also be mobilized to expand the tourist trade through the use of promotions and advertising popular recreational and hospitality venues. As such, tourism has become a popular activity in contemporary society.

In this new era, 'tourism' as we know it has expanded beyond its previously narrow definition. Tourism or recreational activities is no longer solely identified as a long trip to a natural or historical destination with large groups of participants. Today it is common for tourists to spend leisure time in the suburbs, enjoying recreational activities and the culinary while experiencing more classic and rural nuances such as the village. Rural nuances are thought capable of returning images of past life, so it is not uncommon for the connoisseurs of leisure time to capture the places and upload them to social media. As reported by kompas.com, in 2019 many people were interested in natural panoramas and culinary ${ }^{1}$. Further, the village exists as a vacation or entertainment destination because it can fulfill the desire to experience local culinary and natural panoramas. As such, the expansion of the tourist industry into the village, will eventually impact changing economic patterns in rural areas.

In the book entitled "Masyarakat Desa di Indonesia", Koentjaraningrat (1984) defines about the village as a group of people whose living systems depend on agriculture, ${ }^{2}$. Gradually, the effects of capitalization and modernization altered the way people see villages. The village is not just a place of living for people who work in the agricultural sector. Moreover, the village exists as a locus for an economic growth in a variety of forms including tourism and the creative economy, which is based on innovative creation supported by creative industry. Recognizing the village as a key hub for economic opportunity has been crucial for local society and external parties seeking profit through tourism entrepreneurship. ${ }^{3}$

\footnotetext{
1 Anggita Muslimah, "Prediksi Tren Wisata Turis Indonesia Tahun 2019," 18 November 2018, https://travel.kompas.com/read/2018/11/18/113944027/prediksi-tren-wisata-turis-indonesia-tahun-2019.

2 Koentjaraningrat Koentjaraningrat, Masyarakat Desa di Indonesia (Jakarta: Fakultas Ekonomi Universitas Indonesia, 1984).

${ }^{3}$ Ratna Istriyani, "Kontribusi Pemuda dalam Menjawab Permasalahan Sosial Ekonomi Pascabencana," Jurnal Studi Pemuda 4, no. 2 (9 Agustus 2018): 315-29, https://doi.org/10.22146/studipemudaugm.36815.
} 
The potential of the village's economy as a tourist or recreational destination can be determined by three factors. First, the movement of visitors (tourists). Second, the social activities that facilitate visitor movement. Third, the implications of visitor movement and social activities in facilitating visitors ${ }^{4}$ This, the opportunities for visitor movement, will only have economic implications if responded to with the efforts to provide physical facilities and services. Accessibility and the object of attraction are also key supporting factors that influence the strength of a village's tourist economy. ${ }^{5}$ The accessibility refers to the physical access affordability of the location as seen from adequate road access to the transportation modes that can be used. Beautiful natural panoramas are often village's main attraction, they are used as a recreational area for the society, especially urban communities.

The village begun to transform into a destination for entertainment, especially for urban people seeking to experience authentic images of classic nuances. The natural and classic nuances are becoming commercialized by the tourist trade and thus losing their authenticity. Local people package the classic nuances as an entertainment destination. It can be seen from the proliferation of restaurants and cafes in the suburbs and villages. This reality is most clearly demonstrated in Sleman, Yogyakarta. People who visit the village are not only the local community, but also people from outside the region. For example, Klothok Coffe at Kaliurang Street Km 17. The restaurant and coffee shop are actually crowded with people from outside Sleman and the Yogyakarta province. The crowds continue during weekend until the long holidays. ${ }^{6}$

This reality certainly shows a shift towards entertainment and tourism places, especially in rural areas. restaurants and cafes have been closely associated with entertainment facilities commonly found in urban areas that have become an integral component of the urban lifestyle. This article explores the formulas related to the economic shift experienced by villages, particularly in relation to trends in contemporary tourism which refers to the proliferation of restaurants and cafes in rural areas at Sleman. In addition to using the analysis from economy and industrial perspective, this article appeals to sociological contemporary theory to explore the practice of public consumption of space, with particular reference to alterations in rural areas of Sleman relating to trends in tourism and entertainment.

\footnotetext{
${ }^{4}$ Janianton Damanik, Pariwisata Indonesia: Antara Peluang dan Tantangan (Yogyakarta: Pustaka Pelajar, 2013). Hlm 66.

${ }^{5}$ Damanik. Hlm: 67.

${ }^{6}$ Otten Coffee, “PIKNIK' DI WARUNG KOPI KLOTOK YOGYAKARTA," Majalah Otten Coffee (blog), 19 Oktober 2017, https://majalah.ottencoffee.co.id/piknik-di-warung-kopi-klotok-yogyakarta/.
} 


\section{METHODOLOGY}

This article adopts a descriptive qualitative approach, focusing on interactive processes or events. ${ }^{7}$ Qualitative research was chosen for this study, which looked at the process of transforming villages as tourism or recreation areas. It allows researcher to look at restaurants and cafes in rural areas in more depth and understand their nuances. Previously, the village was known as a tourism that provided natural and cultural attractions, outbound experiences, and homestays. But in this era, it is starting to experience a shift against the culinary tourism which has led to the emergence of restaurants and cafes that are actually visited by urban people and outside the region.

The objects of this study are villages in Yogyakarta, especially in Sleman area at the north of Yogyakarta Municipality. These villages have already experienced some economic transformation related to the tourism trend, particularly in terms of the emergence of cafes and restaurants inside the villages.

The data collection technique used in this study is observation in ethnographic research. Observation reputed as an activity of seeing and listening carefully to everything that happens in the research locus. ${ }^{8}$ For the purposes of this study, the objects of observation consist of: (i) the emergence of restaurants or cafes inside the village area, including the activities inside, interior and exterior design, and (ii) the categorization of visitors. In order to enrich the analysis, this study also uses quantitative data as secondary data which this technique is also permitted in qualitative research and other secondary data. ${ }^{9}$ Secondary data in this study includes data on the development of cafes and restaurants in Sleman area, as well as information on tourism trends in Sleman area obtained from social media and bulletin. The analysis techniques use an interactive model by Miles and Hubberman that includes data collection, reduction, data presentation and drawing conclusions. ${ }^{10}$

\section{VILLAGE AS A RECREATION DESTINATION AND ITS TRANSFORMATION}

Studies about the entertainment arena often attract a discussion about the concept of tourism. Therefore, this discussion begins with a definition and description of tourism. Although the concept of tourism can be quite dynamic, it runs linearly with social changes that have taken place in society. Especially, if it is related to recreational needs and consumption modes.

\footnotetext{
7 W. Lawrence Neuman, Metodologi Penelitian Sosial: Pendekatan Kualitatif dan Kuantitatif (Jakarta: Indeks, 2013).

${ }^{8}$ Neuman.

${ }^{9}$ Burhan Bungin (Ed), Analisis Data Penelitian Kualitatif (Jakarta: Raja Grafindo Persada, 2010).

${ }^{10}$ Muhammad Idrus, Metode Penelitian Ilmu Sosial (Jakarta: Erlangga, 2009).
} 
According the World Tourism Organization (WTO), tourism is described as a person's travel activity and temporary living outside his usual environment for leisure time, business and other purposes. ${ }^{11}$ From this it is clear that tourism has already become a fundamental component of contemporary life, spanning from daily activities - such as a work commute - to taking full advantage of leisure time. Taking a moment out from routine activities already became a crucial component of many people's lives. This understanding of tourism is inherently linked to modernization and industrialization which have had profound impact on the division of labor and work activities which are dense and time-bound. Therefore, people are starting to see the importance of leisure time for taking a break from their routine. Leisure time thus becomes something valuable and needs to be used as best as possible.

High social demands for recreational and tourist activities as a utilization of leisure time has led the growth of the tourism sector in Indonesia. The growth of the tourism sector is marked by the proliferation of tourist destination points. It seems that tourism growth or tourism trends cannot be separated from Yogyakarta. Apart from having a title as a city of education and a city of culture, Yogyakarta is also called a tourism destination city. The existence of Yogyakarta as a tourism city can be seen not only from the massive growth of tourist attractions, but also the number of tourist visits which shows an increasing trend from year to year, especially the last five years, based on the data from Tourism Office of Yogyakarta Special Region in 2018. ${ }^{12}$

Graph 1. Data on Tourist Visits in Tourism Attractions in 2014-2018

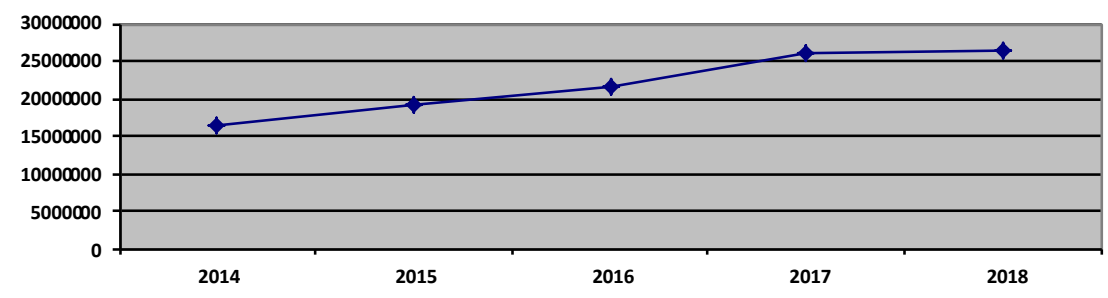

Based on a report collected by Tourism Office of Yogyakarta Special Region and presented in Graph 1. above, the number of tourist visits to destination of tourist attractions from 2014 until 2018 (the last five fears) shows an increasing trend. The significant increases even happened between 2015 and 2017, which saw the rapid proliferation of tourism destinations in Yogyakarta. Yogyakarta has become a paradise for people in need of recreation.

${ }^{11}$ Muljadi Muljadi, Kepariwisataan Dan Perjalanan (Jakarta: Raja Grafindo Persada, 2010).

${ }^{12}$ Tim Penyusun Tim Penyusun, Statistik Kepariwisataan 2018 (Yogyakarta: Dinas Pariwisata Daerah Istimewa Yogyakarta, 2018). 
The increase in visitor quantity is also linked to the economic aspect of tourism growth at several points in Yogyakarta, so the tourism has become a trend in the community economy. One area that shows the growth of recreational destinations is Sleman. This area is on the outskirts of the provincial capital of Yogyakarta, but it is still close to Merapi Mountain. Villages in Sleman are also showing their trends of tourismfueled economic changes, especially in economy and tourism aspects. Several areas close to the main road access, have experienced growth in some recreational destinations such as restaurants, cafes, and other hospitality venues, besides the tourism village which has become a tourism icon of Sleman. In fact, based on the data, the number of cafes in Sleman has increased during the last 3 years. There were 12 cafes in 2016, in 2018 it increased significantly to 22 cafes.

Graph 2. Number of Cafes in Sleman 2016-2018

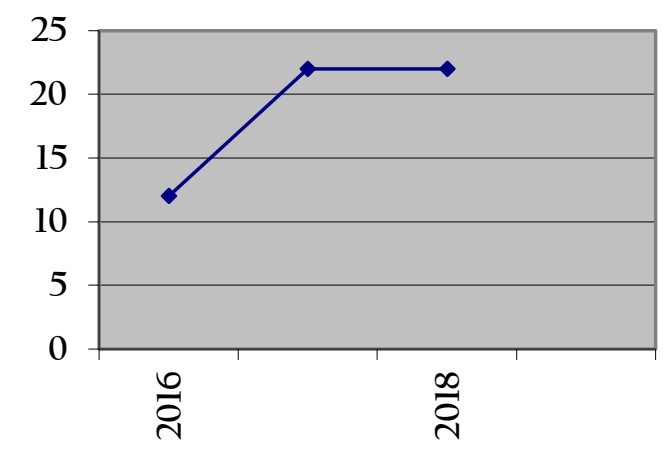

Source: DIY Tourism Office 2018

Along with the shift of lifestyle in the community's life, the community's need for recreation and the way people use their leisure time also changes. Leisure time is often used to relax with friends, and relatives. The choice of destination is conditioned by a number of factors including comfort, location, affordability, as well as a rising nostalgia for nature or classic nuances of rural areas. As a result, the village has become an increasingly popular option for people (especially urban communities) to fulfill their needs, or as a means of escaping for a short time from their routine.

Changes to the use of leisure time also appears to affect the existence of the village as a recreational destination. Initially, the conceptualization of the village did not frame it as a place for recreation. Rather, the village was originally used as a location for outbound games or family gatherings. Therefore, the villages that were referred as a tourism villages have become a campus' choices and other institutions as a location for outdoor activities. ${ }^{13}$ Over the past three years the village, conceptualized as a recreation area, has evolved and expanded beyond outbound or family gatherings. This change leads to indicative of a

${ }^{13}$ Machya Astuti Dewi dan Sri Issundari, "Desa Wisata Sebagai Aset Soft Power Indonesia” 29, no. 02 (2016): $64-74$. 
tourism trend which has shifted towards culinary and places that provide some nostalgic needs. ${ }^{14}$ Graph 2 shows the increasing number of tourist café businesses in Sleman area, this trend has penetrated the suburbs and villages.

High demand for recreational places that provide culinary, classic, and natural nuances has influenced the emergence of restaurants or cafes in villages and suburbs. The social setting of the village is closely related to natural scenery, as such, it becomes a strategic location for tourist to ensure the pleasure. Based on the records of the tourist information provider sites, beside cafes, restaurants are also emerging in rural areas. At least, there are 7 selected restaurants in Yogyakarta which not only serve culinary delights, but are located against the landscape of the rice fields, adding classic and natural nuances to the culinary experience..$^{15}$

Figure 1. Resto Wirosani on Palagan Street Km. 13 Sleman

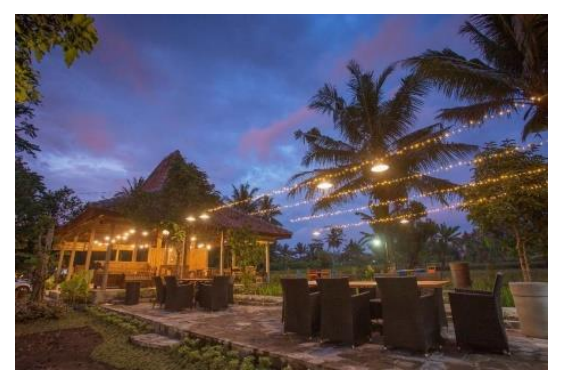

Source: https://www.idntimes.com/food/dining-guide/fatiya-1/7-tempat-makan-denganview-sawah-paling-adem-di-Yogyakarta-bikin-betah-clc2/full

Figure 1 shows one of the restaurants, as a manifestation of the village transformation into a picnic or tourism spot. The restaurant named Wirosani is located at Palagan Street Km. 13 Sleman Yogyakarta. This restaurant is located 12 kilometers north of Tugu Yoyakarta in the rural areas. This restaurant offers classic nuances in the middle of rice fields with a joglo building and tables set outdoors. The menu offered is also a traditional Javanese menu and typical of ndeso (village). This venue is very 'instagramable,' that enact people to took picture and upload it into their social media account. This becomes an important characteristic for encouraging more tourists to visit. In addition, a Klothok Coffee Shop located at Kaliurang Street, 10 kilometers from the city center. Klothok Coffee Shop has a traditional culinary concept and is located on the edge of the rice fields.

\footnotetext{
${ }^{14}$ Muslimah, "Prediksi Tren Wisata Turis Indonesia Tahun 2019."

15 Fatiya Fatiya, "7 Tempat Makan dengan View Sawah Paling Adem di Jogja, Bikin Betah.," 1 Juli 2018, https:/www.idntimes.com/food/dining-guide/fatiya-1/7-tempat-makan-dengan-view-sawah-paling-ademdi-jogja-bikin-betah-clc2/full.
} 
The existence of the village as a place for urban community to enjoy their leisure time has become an advantage for local communities. So far, the village management involved local communities. Sleman area showed that the village packaging as a tourism location or entertainment destination grows due to the efforts and cooperation of local communities because of the awareness of their economic potential. As such, villages are increasingly managed in such a way to provide economic benefits from the tourism trade, not only from the agrarian sector. Economic diversification in the village can provide economic benefits for the community. The growth of the tourism industry in rural areas also does not necessarily get resistance from the local community.

Notwithstanding, the economic potential of the village can also be mobilized by capital economic actors. This reality is common in Sleman Yogyakarta, especially in villages that have natural potential and strategic locations with easy access routes. Capital economic actors have a variety of characters and motives. While some are just looking for profits by maximizing the existing capital, the tourism business not only provides personal benefits, but also empowers local communities by involving them in tourism management. Thus, the local community directly experiences the economic benefits from tourism in their villages.

\section{TRANSFORMATION OF TOURISM IN THE VILLAGE ON INDUSTRY AND ENTREPRENEURSHIP STUDIES}

Studies about tourism or tourism businesses in a village area are often linked to their socioeconomic impacts on the community. Research conducted at Borobudur Temple, Central Java, by Hamzah et al explained that the transformation of the village into a tourist destination has an ambivalent impact, that is positive and negative. The positive impacts of tourism include the opening up of job opportunities to become tourism workers and trade businesses. These employment opportunities are also linked to the improvement of education levels. As for the negative impact of the village transformation is the change of profession becomes a tourism park worker, commercializing and diluting local nuances and wisdom. Moreover, tourism has changed the pattern of people's lives and affected population density due to people travelling to take advantage of economic opportunities. ${ }^{16}$ A similar result was also described by Wulandari in her research at Kersik Tuo Village, Kerinci Regency. In her description, she explained that the growth of tourism in the

${ }^{16}$ Faizal Hamzah, Hary Hermawan, dan Wigati Wigati, "Evaluasi Dampak Pariwisata Terhadap Sosial Ekonomi Masyarakat Lokal," Jurnal Pariwisata 5, no. 3 (14 Oktober 2018): 195-202, https://doi.org/10.31311/par.v5i3.4434. 
village, such as natural tourism of Kerinci Mountain, has provided employment and tourism business opportunities in Kersik Tuo Village. ${ }^{17}$

In contrast to the research above, related to the tourism and recreation areas, this article explores and describes the reality of the shifts in villages becoming tourist destinations, especially, shifts associated with today's tourism trends. The tourist trend itself experiences changes or transformations along with social changes in society. Tourism is an aspect of the psychological needs of the community. It has turned into a business that is not only about growing and managed technocratically or centrally through the related agencies. In reality, the community also has the ability to experience the economic trends and opportunities, especially in the relation with tourism transformation itself. Recreational areas which go viral (popular) on social media have grown massively, especially in Sleman Yogyakarta. The trend of places that combine natural and culinary delights which are 'instagramable,' such as restaurants and cafes, are becoming a popular choices for many people.

Referring to the changes in tourism trends along with the recreational needs and the way people enjoy them, this article also describes the context of tourism activities. Tourism or recreational activities are often associated with the utilizing or ownership of leisure time. The term 'leisure time' was popularized by Thorstein Veblen with the word 'leisure,' which at that time was related to industrial society. Leisure is defined as a nonproductive consumption of time.

The non-productive consumption of time is based on an assumption related to the unworthiness of productive work and become an indicator of wealth (pecuniary ability) to produce a lazy lifestyle. In other words, leisure and laziness are concerned with style, not work ethic. In addition, people who have leisure style are consider to occupy the 'rich' category. Therefore, the study of leisure consumption becomes an interesting focus point in here, not only to show its function denotatively, but connotatively.

The emphasis on leisure can be seen as an attempt to become the center of attention. In other words, people who have leisure belong to the 'upper class,' which is often referred to as the 'leisure class'. The leisure class is considered to have a higher stratum compared with the workers or employees who are engaged in productive work, who can be seen as lacking financial security. ${ }^{18}$ In other words, 'leisure' is a symbol that defines the meaning or identity of a certain class, which is called the leisure class.

If we borrow Piere Bourdie's term, leisure is a kind of habitus and symbolic capital that belongs to a certain class. The habitus because of leisure leads to dispositions system

17 Dwi Pratiwi Wulandari, "ANALISIS DAMPAK PERKEMBANGAN PARIWISATA TERHADAP PERUBAHAN KONDISI SOSIAL EKONOMI MASYARAKAT DESA KERSIK TUO KECAMATAN KAYU ARO KABUPATEN KERINCI," Ensiklopedia of Journal 1, no. 1 (9 November 2018): 27-35, https://doi.org/10.33559/eoj.vlil.19.

${ }^{18}$ Thorstein Veblen, The Theory of the Leisure Class (Floating Press, 2009). 
(attitudes or behaviors) including cognitive and affective dimensions. The symbolic capital of leisure can be used to communicate the class or status system in social and arena practices.

When contextualized with the current era, one of the non-productive uses of time can be associated with recreation or tourism activities. ${ }^{19}$ Such activities are not productive work, but pursued just for fun, or relieving fatigue by looking for an entertainment. However, this definition can be said different with the term of laziness or idleness conveyed by Veblen. Recreation and tourism are not always associated with laziness or wasting time. Rather, recreation is an activity for taking advantage of the available time to entertain yourself. This appears to have become a 'necessity' in contemporary society. The needs in this case are not always born naturally from internal motives, but from external construction by economic actors that called the new consumption era.

Another difference described by Veblen is the term of leisure time which is used for non-productive activities belonging to the wealthy or leisure class. Veblen's concern about the leisure class is different from today's era. Because Veblen talked about this class in the context of industrial society that dividing the social class into two parts, those are the owner of production tools and the worker or laborer class. The social stratification in work division was also conveyed by Karl Marx with the terms of Bourgeois Class (owners of the production tools) and proletariat (workers or employees). ${ }^{20}$ In the industrial era, the working class is always engaged in productive activities due to their position in the circle of production relations. They exist in direct control of the owner of the production tools. Meanwhile, the owner of the production has the discretion to regulate, including the ownership of leisure time. They are able to ensure that running production and the wealth flows through the laborers which they employed.

The context is absolutely different from today's post-industrial era. Especially with the Yogyakarta context, which is not an industrial city concerned with the mass production of goods. Likewise, with the surrounding areas. In urban areas, most people work in government, education services and tourism. Others work in the informal sector such as trade. Yogyakarta is a city of education and tourism. More specifically, tourism also grows in agricultural area. Yogyakarta has experienced high levels of migration, particularly college students. This has altered the population profile and obscures the leisure class category referred to by Veblen.

Based on this, the utilization of leisure time in the form of recreational activities is owned by the class with the varied compositions. However, referring to Veblen's theory about orientation that want to be seen (existence), tourism or recreational activities are still seen as representative of a particular lifestyle. This is increasingly visible due to the use of social media to showcase recreational activities.

\footnotetext{
${ }^{19}$ Faisal Basri, Pierre Bourdieu: Menyingkap Kuasa Simbol (Yogyakarta: Jalasutra, 2014). Hlm: 109.

${ }^{20}$ Karl Marx, Filsafat Kemiskinan. Terjemahan Oey Hay Djoen (Dey’s Renaissance, 2007).
} 
The reality of or recreation as a lifestyle or trend has had a domino effect on many people who are tempted to do the similar activities and upload them to social media. There are increasing numbers of of portals and accounts dedicated to inform people about particular places for recreational activities or just hanging out. This information becomes a reference for the public in using their leisure time. Not limited to giving information, portals or social media accounts also display photo albums of people who have visited there. The ability to upload and link particual recreational photos and spots directly impacts their presence and visibility on social media ${ }^{21}$.

Figure 2. Account of Jogja Culinary and Tourism Info on Instagram

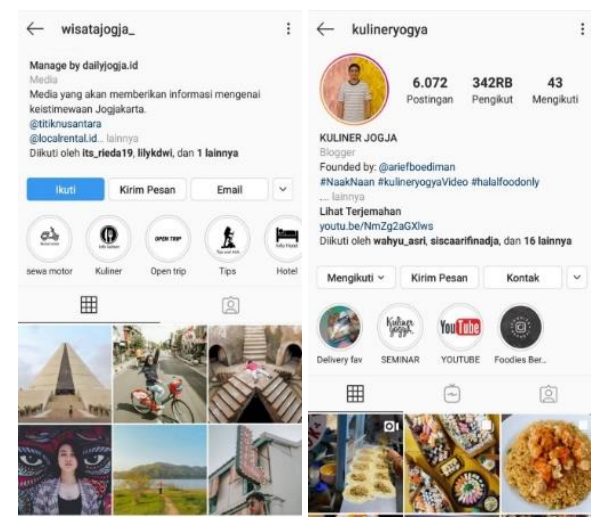

Source: Instagram

The utilization of leisure time is felt more on weekends or long holidays but is not always linked to these holidays. Towards the weekend or holidays, people will start thinking about what they will do during a public holiday (red date), weekend, or long holiday. This is supported by tourism information and holiday spots that overwhelm web pages and social media such as Instagram. As such, it seems that the mindset about the importance of using leisure time is directly proportional to the growth and development of recreational and tourist spots today.22

As described in the previous sub-chapter, tourism or recreation area have undergone many transformations. It has begun to grow in rural areas as a locus. This is also in line with the utilization of leisure time in the form of recreational activities. The high interest of people in recreational facilities seems to have provided a new perspective towards the tourism including the perception that tourism is a necessity and is often constructed as an alternative provider of economic opportunities.

\footnotetext{
${ }^{21}$ Damanik, Pariwisata Indonesia: Antara Peluang dan Tantangan.

22 Christina Pambudi, dkk, "Waktu Luang dan Dinamika Kepariwisataan," 9 September 2019, https:/crateridea.blog.uns.ac.id/2016/09/09/waktu-luang-dan-dinamika-kepariwisataan/.
} 
Referring to the village as a destination for tourism or recreation which provides culinary and nostalgia with nature and classical culture, is no different than showing that tourism has become a part of promising industry or business. In this case, industry is often associated with the production activities by turning raw materials into ready-to-consume goods, adding economic value. However, the definition is not always appropriate, and it seems that it is necessary to look into current Indonesian economic context, which is not only targeting production activities but also natural resource management and manufacture.

Through the Badan Ekonomi Kreatif (Creative Economy Agency), Indonesia is promoting alternative economic concepts in addition to the oil and gas and manufacturing industries. This alternative economy is what called the 'creative economy.' That is, creativity that was previously considered a minor aspect but has become an alternative for the problems of socio-economic community development. The creative economy sector is expected to become the backbone of the Indonesian economy, optimizing creative opportunities. ${ }^{23}$

One of the creative economy's targets is the tourism sector itself. Moreover, the recently inaugurated government has begun to boost the tourism sector so it can contribute optimally to the economy. Through his presentation, the Minister of Tourism and Creative Economy - Wishnutama emphasized that the creative economy and tourism are inseparable sectors. Both can increase the economy as a source of foreign exchange. Thus, the creative economy and tourism can synergize. ${ }^{24}$

Tourism, as an industry, is starting to receive a serious attention due to its significant impact on the Indonesian economy. People are increasingly paying attention to this sector as an economic base that can dramatically contribute to change. This can be illustrated by culinary, which starts to pay attention to the location aspects and design so that the village has an attraction for the growth of the tourism business.

The high interest towards the use of the time in recreational activities and a growth through the synergy of tourism with the creative economy encourages the development of ideas and tourism trends or a new recreation area, especially in villages. The tourism trend is a manifestation of entrepreneurial activities (entrepreneurship). This term has been introduced by Joseph Schumpeter with the term of creative destruction. Entrepreneurship is a behaviour oriented towards the utilization of opportunities. This opportunity is borne from efforts to catch and respond to changing social trends. The use of opportunities is

\footnotetext{
23 Redaksi Retas Redaksi Retas, “Memperkuat Komunitas, agar Monetisasi Terus Menerabas," Retas, Desember 2016.

${ }^{24}$ Jannisha Rosmana Dewi, "Serah Terima Jabatan, Wishnutama Siap Sinergikan Ekonomi Kreatif dan Pariwisata," Badan Ekonomi Kreatif (blog), 24 Oktober 2019, https://www.bekraf.go.id/berita/page/8/serahterima-jabatan-wishnutama-siap-sinergikan-ekonomi-kreatif-dan-pariwisata.
} 
based on creativity for change and productivity. By referring to the Schumpeter's term, it is quite common that entrepreneurship is also considered creative action..$^{25}$

The growth of the tourism industry in villages, demonstrated by the proliferation of cafes and restaurants, shows how creative economic actors see the village as an economic opportunity. This opportunity comes from the analysis of changing trends which occurred in society. In this case it is a way for people to take advantage of their leisure time, anyone who often uses their leisure time with more recreational activities, as well as their favorite tastes ${ }^{26}$.

As explained in the previous paragraph, it is now actually common to find that society prefer simple, but Instagramable recreational activities. Gather with the closest person in a quiet place, reminisce in a classic and natural atmosphere while enjoying a meal that complements the feeling of togetherness. ${ }^{27}$ These needs are mainly for urban communities who have demanding work routines every day. Culinary and tourist business packages in the village are able to meet these recreational needs. Additionally, the capacity of a venue to fulfill an Instagramable criteria is increasingly important, taking pictures or selfies as a part of leisure time is considered increasingly important by today's society. As such, restaurants and cafes in village areas not only provide a place for culinary, but also arrange the space in such a way to fulfill the Instagramable-worthy criteria.

Figure 3. Instagramable Corner of Marisini Coffee
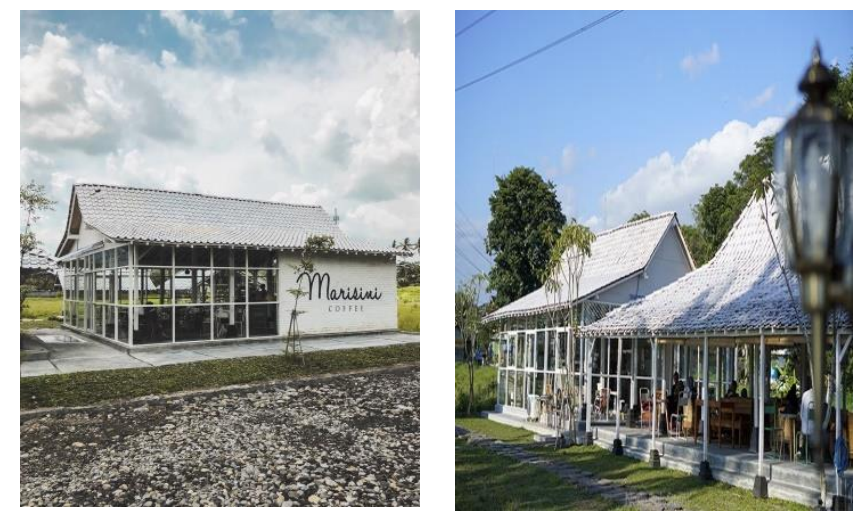

Source: travelingyuk.com/marisini-coffee/170212/

Figue 3 shows the instagramable corner located at the village in the side of Kaliurang Street. It is arranged in a semi-open classic nuance design because it adapts to the surrounding environment that is still surrounded by rice fields area. This place is often used by visitors for selfies, especially at dusk.

\footnotetext{
${ }^{25}$ Peter. F Drucker, Innovation and Entrepreneurship: Practice and Principle (California: Perfect Bound, 1984).

${ }^{26}$ Dewi dan Issundari, "Desa Wisata Sebagai Aset Soft Power Indonesia."

${ }^{27}$ Muslimah, "Prediksi Tren Wisata Turis Indonesia Tahun 2019."
} 
The need to utilize leisure time has indeed reframed the village as a potential destination for recreation activities, bringing new economic opportunities to the village, contributing to economic development of the village community. This study contributes to existing research by providing an overview of the implications of correlating trends in using leisure time, tourism trends, and shifting the economic pattern in the village. Therefore, it is necessary to ensure that the utilization of tourism business opportunities in the village have positive economic impacts on local communities. One example is the protection or supervision of business licenses through local governments. Through the use of protective measures, negotiations and cooperation local communities can be involved in and empowered by the economic opportunities afforded by the expansion of the tourist trade into the village.

\section{THE VILLAGE IN NEW CONSUMPTION ERA}

The transformation of the tourism business, especially the expansion of culinary venues such as restaurants and cafes in rural areas, provides a new perspective on the village. Villages are no longer seen as isolated areas that are difficult to change and are solely concerned with the agrarian sector. Referring to the description above, villages (especially in the Sleman region) have often become recreational destinations and lead the proliferation of restaurants and cafes in villages.

The transformation of the village into a recreational destination in the Sleman region, until the proliferation of restaurants and cafes, can be conceptualized in two aspects. First, the relationship between city and village. Second, the village as a consumed space which needs to be studied in the new consumption theory.

The connectivity between village and city in the Sleman region, is supported by adequate transportation facilities, supporting high mobility between them. Furthermore, it affects a domino change, spreading from the center to edges. The information flow also supports changes to the village portrait through cyberspace. This accessibility which, according to Janianton Damanik, also determines people's interest in visiting and influencing the growth of the village as a recreational destination. The easiness for accessing the transportation and information attracts mobility for recreation to the village area. $^{28}$

Understanding the village as a consumed space implies that the village represents a somewhat commercialized and commodified space for consumers. Research conducted by Wibowo, Udasmoro and Noviani shows that the massive scale of internet café's in Yogyakarta represents a new consumption model. Consumers who routinely visit internet cafes not only aim to access the wifi or the internet, as in internet stall in the previous era. They are also motivated by the culinary and aesthetic nuances (interior and exterior

\footnotetext{
${ }^{28}$ Damanik, Pariwisata Indonesia: Antara Peluang dan Tantangan. Hlm: 67.
} 
design) of the venue. In other words, while surfing in the virtual room, they can also relax and enjoy the space (café) which is laid out in an attractive and entertainment-oriented fashion. Referring to the review, it can be said that internet cafes accommodate the changes in the form, function, facilities and consumption practices of users (consumers). ${ }^{29}$

Relating to the transformation of the village into a recreational destination, the authors saw a similar pattern for the consumption of space. However, the context of this space does not only refer to the restaurant or café buildings, but also where they are located. This is important, considering that the aesthetic value of the café is not only seen from the design but also the panorama which surrounds it. In fact, panoramas can be the most important aspect of recreation areas. The village setting provides a classic, natural nuance, maintaining aspects of the past that attract people to spend their leisure time. As such, the spatial context of cafes and restaurants is not only seen from the architecture or lighting, but the panorama outside. This is demonstrated by the scenic location of a number of restaurants and cafes in rural areas at Sleman Yogyakarta (see figures 1 and 3).

Digging deeper into contemporary consumption culture, what is consumed can be demonstrative of the prestige and classification of a person's status. This statement refers to Jean Budrillard's criticism towards the commodity theory developed by Marx. For him, a commodity not only has a 'use' and an 'exchange' value, but also a 'sign' value. In other words, a commodity is not only contains a function and price, but also shows expressions and signs of lifestyle, prestige, luxury, power and so on. ${ }^{30}$ In conclusion, when people consume objects, they consume signs, and in the process, they define themselves.

On this criticism, Baudrillard underlines that industry (capitalism) is not only determined by the momentum of production, but also the momentum of consumption, which is strongly affected by the operation of signs in the product or commodity. The scale of the tourism business, such as cafes and restaurants in the village, seems to be affected by the signs of the space in which they are offered and consumed.

Consumption and expressions of signs are supported by smartphones which play a crucial role in the consumption of space. In this case, the manifestation of space consumption is not only seen by consumers enjoying the architecture and facilities of restaurants and cafes in rural areas. The enjoyment of capturing visual images via smartphones and uploading them to social media is further evidence of the social consumption of space. In their posts, consumers often provide a hashtag, mention, or location where the photo was taken. They visualize and upload the space through the

\footnotetext{
${ }^{29}$ Tangguh Okta Wibowo, Wening Udasmoro, dan Ratna Noviani, "Understanding New Consumption Sites of Internet Cafe in Yogyakarta, Indonesia," Jurnal Ilmu Sosial Dan Ilmu Politik 23, no. 3 (21 Mei 2020): 237-49, https://doi.org/10.22146/jsp.51707. Hlm. 238.

30 Goerge Ritzer, Teori Sosial Postmodern. Terjemahan Muhammad Taufik (Yogyakarta: Kreasi Wacana, 2010). Hlm: 139.
} 
publication of images that convey an aura of being exclusive, contemporary, and trendy. These images, as a representation of the consumption of space, contributes to the determining of the authors identity. As such, it finds a conformity with Veblen's theory, which claimed that leisure as a 'non-productive activity' of consuming time that is orientated toward gaining the attention of others. ${ }^{31}$

\section{CONCLUSION}

The high enthusiasm of the community on the use for leisure time with recreational activities has supported the growth of the tourism industry in Indonesia, without exception Yogyakarta, especially Sleman. Tourist activities themselves have undergone a shift in relation to the high interest in destinations that are able to provide natural nuance and culinary experiences. The village area has become a representative location to meet these needs. For business actors, the high rate of using leisure time as a recreational activity and the desire for natural recreational destinations and serving culinary is seen as an opportunity. As such, the village area has experienced significant transformation into a recreational destination, demonstrated by the rise of restaurants and cafes. In addition, a new consumption mode, that is the consumption of space and signs, has also contributed to the transformation of contemporary village into recreation areas.

\section{ACKNOWLEDGMENT}

Author would like to thank the reviewer who has commented on this paper. Author would also like to thank academic colleagues who provided many discussions on the topic of writing.

\section{COMPETING INTEREST}

None

\section{REFERENCES}

Basri, Faisal. (2014). Pierre Bourdieu: Menyingkap Kuasa Simbol. [Pierre Bourdieu: Unveiling The Power Of Symbols] Yogyakarta: Jalasutra.

Bungin (Ed), Burhan. (2010). Analisis Data Penelitian Kualitatif. [Qualitative Research Data Analysis] Jakarta: Raja Grafindo Persada.

Coffee, Otten. (2017). Piknik Di Warung Kopi Klotok Yogyakarta. [Piknik 'At The Kopi Clothes, Yogyakarta] Majalah Otten Coffee (Blog), 19 Oktober 2017. Https:/Majalah.Ottencoffee.Co.Id/Piknik-Di-Warung-Kopi-Klotok-Yogyakarta/.

Damanik, Janianton. (2013). Pariwisata Indonesia: Antara Peluang Dan Tantangan. [Indonesian Tourism: Between Opportunities And Challenges]Yogyakarta: Pustaka Pelajar.

31 Veblen, The Theory of the Leisure Class. 
Dewi, Jannisha Rosmana. (2019). Serah Terima Jabatan, Wishnutama Siap Sinergikan Ekonomi Kreatif Dan Pariwisata. [Handover Of Position, Wishnutama Ready To Synergize Creative Economy And Tourism] Badan Ekonomi Kreatif (Blog), 24 Oktober 2019. Https:/Www.Bekraf.Go.Id/Berita/Page/8/Serah-Terima-JabatanWishnutama-Siap-Sinergikan-Ekonomi-Kreatif-Dan-Pariwisata.

Dewi, Machya Astuti, Dan Sri Issundari. (2016). Desa Wisata Sebagai Aset Soft Power Indonesia [ Tourism Village As Indonesia's Soft Power Asset] 29, No. 02: 64-74.

Drucker, Peter. F. (1984). Innovation And Entrepreneurship: Practice And Principle. California: Perfect Bound.

Fatiya, Fatiya. (2018). 7 Tempat Makan Dengan View Sawah Paling Adem Di Jogja, Bikin Betah. [ 7 Places To Eat With The Coolest Rice Field View In Jogja, Make You Feel Good] 1 Juli 2018. Https:/Www.Idntimes.Com/Food/Dining-Guide/Fatiya-1/7Tempat-Makan-Dengan-View-Sawah-Paling-Adem-Di-Jogja-Bikin-BetahClc2/Full.

Hamzah, Faizal, Hary Hermawan, Dan Wigati Wigati. (2018). "Evaluasi Dampak Pariwisata Terhadap Sosial Ekonomi Masyarakat Lokal." [Evaluation Of The Impact Of Tourism On The Socio-Economic Of Local Communities] Jurnal Pariwisata 5, No. 3: 195-202. Https://Doi.Org/10.31311/Par.V5i3.4434.

Idrus, Muhammad. (2009). Metode Penelitian Ilmu Sosial. [Social Science Research Methods] Jakarta: Erlangga.

Istriyani, Ratna. (2018). Kontribusi Pemuda Dalam Menjawab Permasalahan Sosial Ekonomi Pascabencana. [Contribution Of Youth In Responding To Post-Disaster Socio-Economic Problems] Jurnal Studi Pemuda 4, No. 2: 315-29. Https://Doi.Org/10.22146/Studipemudaugm.36815.

Koentjaraningrat, Koentjaraningrat. (1984). Masyarakat Desa Di Indonesia. [Village Communities In Indonesia] Jakarta: Fakultas Ekonomi Universitas Indonesia.

Marx, Karl. (2007). Filsafat Kemiskinan. Terjemahan Oey Hay Djoen[Poverty Philosophy. Oey Hay Djoen's Translation]. Dey's Renaissance.

Muljadi, Muljadi. (2010). Kepariwisataan Dan Perjalanan. [Tourism And Travel] Jakarta: Raja Grafindo Persada.

Muslimah, Anggita. (2018). Prediksi Tren Wisata Turis Indonesia Tahun 2019, [ Predictions Of Indonesian Tourist Trends In 2019] 18 November 2018. Https://Travel.Kompas.Com/Read/2018/11/18/113944027/Prediksi-Tren-WisataTuris-Indonesia-Tahun-2019.

Neuman, W. Lawrence. (2013). Metodologi Penelitian Sosial: Pendekatan Kualitatif Dan Kuantitatif. [Social Research Methodology: Qualitative And Quantitative Approaches] Jakarta: Indeks.

Pambudi, Dkk, Christina. (2019). "Waktu Luang Dan Dinamika Kepariwisataan,"[ Free Time And Tourism Dynamics] 9 September 2019. Https://Crateridea.Blog.Uns.Ac.Id/2016/09/09/Waktu-Luang-Dan-DinamikaKepariwisataan/.

Redaksi Retas, Redaksi Retas. (2016). Memperkuat Komunitas, Agar Monetisasi Terus Menerabas. [Strengthening The Community, So That Monetization Continues To Serve]. 
Ritzer, Goerge. (2010). Teori Sosial Postmodern. Terjemahan Muhammad Taufik.[ Postmodern Social Theory. Muhammad Taufik's Translation] Yogyakarta: Kreasi Wacana.

Tim Penyusun, Tim Penyusun. (2018). Statistik Kepariwisataan 2018. [Tourism Statistics 2018] Yogyakarta: Dinas Pariwisata Daerah Istimewa Yogyakarta.

Veblen, Thorstein. (2009). The Theory Of The Leisure Class. Floating Press.

Wibowo, Tangguh Okta, Wening Udasmoro, Dan Ratna Noviani. (2020). Understanding New Consumption Sites Of Internet Cafe In Yogyakarta, Indonesia. Jurnal Ilmu Sosial Dan Ilmu Politik 23, No. 3: 237-49. Https://Doi.Org/10.22146/Jsp.51707.

Wulandari, Dwi Pratiwi. (2018). Analisis Dampak Perkembangan Pariwisata Terhadap Perubahan Kondisi Sosial Ekonomi Masyarakat Desa Kersik Tuo Kecamatan Kayu Aro Kabupaten Kerinci."[Analysis Of The Impact Of Tourism Development On Changes In Social Economic Conditions Of The Community Kersik Village Tuo Kecamatan Kayu Aro Kabupaten Kerinci] Ensiklopedia of Journal 1, no. 1: 27-35. https://doi.org/10.33559/eoj.vlil.19. 